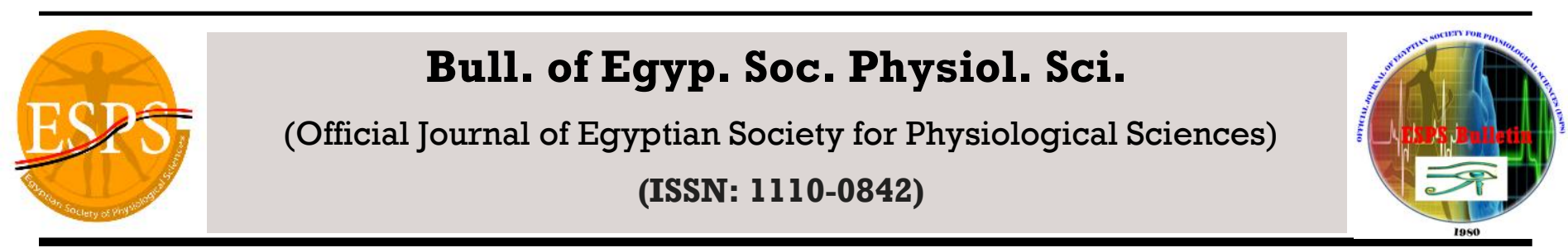

\title{
Functional and Structural Study on the Effect of Curcumin on Folic Acid- Induced Acute Kidney Injury in Albino Rats
}

\author{
Ghada S Mahmoud ${ }^{1}$, Ayman S. Amer², Dalia Gamal ${ }^{1}$ \\ Departments of Human Physiology' ${ }^{1}$, Human Anatomy and Embryology², \\ Faculty of Medicine, Assiut University, Assiut, Egypt
}

Received: Oct $16^{\text {th }}, 2014$ Accepted: Dec 5, 2104 Available online: Dec 20, 3014

\section{Keywords}

- Acute kidney injury (AKI)

- Curcumin (CUR)

- Folic acid (FA)

- Interleukin-6 (IL-6)

- Inerleukin-10 (IL-10)

- Tumor necrosis factor-alpha (TNF- $\alpha$ )

\begin{abstract}
Objective. Systemic administration of folic acid (FA) in rats was used for studying the pathogenesis associated with acute renal damage. However, the mechanism by which FA induces renal damage remains poorly understood. Up to our knowledge, no effective preventive or therapeutic drugs have been developed to protect against acute kidney injury. Curcumin (CUR) is commonly used worldwide as a spice and has been demonstrated to possess various biological activities. The present study was planned to investigate the effect of folic acid administration on renal function, inflammatory cytokines and associated histological as well as ultrastructural changes in renal tissue. In addition, we examined the possible protective effect of curcumin on a rat model of folic acid (FA)-induced acute kidney injury (AKI). Methods. Rats were divided into 3 groups; (FA) folic acid treated group rats were exposed to FA (250 mg/kg) i.p. injection as a single dose. (FA+CUR) folic acid plus curcumin treatment group rats were given curcumin (200 $\mathrm{mg} / \mathrm{kg}$ ) orally administered by gavage daily for 11 days prior to folic acid (250 $\mathrm{mg} / \mathrm{kg}$ ) i.p injection and the last dose of curcumin was given one day after folic acid injection. Control group are given distilled water orally by gavage daily for 12 days and saline i.p. as a single dose on the $11^{\text {th }}$ day. Animals were scarified one day following i.p. injection in all groups. Deterioration of kidney function was detected by blood urea and creatinine levels. Inflammatory response was monitored with blood levels of interleukin-6 (IL-6), interleukin-10 (IL-10), and tumor necrosis factor (TNF- $\alpha$ ). Results. We found that FA treatment significantly raised blood urea, creatinine, IL-6, IL-10, TNF- $\alpha$ levels and caused marked structural changes of the kidney. CUR treatment for 12 days significantly reduced blood urea, IL-6, IL-10, TNF- $\alpha$, and protected partially against renal structural damage. Conclusion. These findings suggest that curcumin is a promising protective agent against AKI induced by FA.
\end{abstract}




\section{INTRODUCTION}

Acute renal damage is considered as a major clinical issue since it affects many critically diseased patients ${ }^{1}$. Toxic, ischemic, as well as inflammatory factors were found to be combined causes underlying acute renal damage ${ }^{1}$. Folic acid is a commonly used compound to study the pathophysiology associated with acute renal failure ${ }^{2}$. Curcumin, a bright yellow aromatic powder commonly used as spice, was found to have a beneficial effect on acute kidney injury (AKI) markers ${ }^{3}$. Acute kidney damage is defined as a rapid decrease in the glomerular filtration rate leading to retention and elevation of blood urea and creatinine levels ${ }^{4}$. Previous studies showed a correlation between proinflammatory cytokines and renal injury ${ }^{5,6}$.

Numerous previous studies, including in vitro and animal experiments suggest a major impact of tumor necrosis factor-superfamily (TNFSF), interleukin-6 (IL-6) and interleukin-10 (IL-10) in inflammatory, malignant, and autoimmune diseases. Members of the TNFSF of cytokines are the key mediators of renal injury ${ }^{5}$. Necrosis and apoptosis were found to be the major histological changes in nephrotoxic AKI ${ }^{7}$. The remaining slightly injured tissues are considered as a source of immunological signals that activate the immune system resulting in further damage of renal tissues 8,9 . Folic acid nephropathy is a model of AKI characterized by acute renal failure and tubuleinterstitial inflammation ${ }^{10}$. Up to our knowledge no previous study investigated the role of IL- 6 and IL-10, or CUR in folic acid-induced acute renal damage. This study was designed to investigate the mechanisms underlying folic acid induced renal damage by measuring the inflammatory markers IL-6, IL-10, and TNF- $\alpha$ as well as the histological and ultrastructural changes in the kidney. In addition, we assessed the role of curcumin as a potential intervention to ameliorate the folic acidinduced changes in the proinflammatory markers and renal structure.

\section{MATERIALS AND METHODS}

\section{Drugs and chemicals}

Folic acid (FA) Oxford (Laboratory Reagent) C19H19N7O6 M.W: 441.40 CAS NO: 7791-13-1 (Assay (by complexometry): 97-102\% PKD by Oxford laboratory Mumbai-400 002, India; Batch NO: 208092 was dissolved in $1 \mathrm{ml}$ distilled water and given as a single dose of $250 \mathrm{mg} / \mathrm{kg}$ i.p. injection ${ }^{2}$. Curcumin Crystalline (CUR) 99\% extra pure, Batch NO. C0632 (Alpha Chemika, Savgan Heights, 102, B wing, RTO Lane, Andheri (W), Mumbai-400 053, Maharashtra, India) was dissolved in $1 \mathrm{ml}$ distilled water and administered orally by gavage immediately after preparation as single daily dose of $200 \mathrm{mg} / \mathrm{kg}$ for 12 consecutive days ${ }^{3}$. Rat TNF-alpha ELIZA Kit (K0331196) Koma Biotech INC. AVITEX CRP (Ref OD073/OD023/OD023/E) Omega Diagnostics.

Rat Interleukin-6 (IL-6) ELIZA Kit (Koma Biotech INC, Cat NO. K0331229). Rat Interleukin-10 (IL-10) ELISA Kit (Koma Biotech INC, Cat NO. K0332134). Both IL-6 and IL-10 company address the same (19F, IS BIZ Tower, Sunyudo Station 1cha, Yangpyeong-dong 5 ga 1-1, Yeongdeungpo-gu,Seoul 150-105, South Korea). Creatinine Jaffe. Colorimetric - kinetic (Diamond Diagnostics, 333 Fiske St, Holliston, MA 01746, United States, REF 2 x 100 ml). Urea-Kit S 180 
(Biomerieux sa, 69280 Marcy-l'Etoile/ France, REF 61912).

\section{Animal preparation and experimental approach}

Experiments were performed on a total number of 18 adult male albino rats weighing 115-150 grams. Animals were obtained from the animal's house facility, Faculty of Medicine, Assiut University, Assiut, Egypt. Two days before experimentation, the animals were kept in the laboratory for accommodation in the condition of 12 hours light/ dark cycle with free access to standard rat chow and tap water. The experiments were carried out according to the protocol approved by the Local Ethical Committee of the Faculty of Medicine, Assiut University in accordance with the ethical guidelines for scientific research in conscious animals.

Animals were randomized into three groups, six animals each: FA-treated group rats were given distilled water orally by gavage for 12 days and exposed to FA $(250 \mathrm{mg} / \mathrm{kg})$ i.p. injection as single dose on the eleventh day. FA+CUR treatment group rats were given curcumin $(200 \mathrm{mg} / \mathrm{kg})$ orally administered by gavage daily for 12 days: 11 days prior to folic acid i.p. injection and 1 day thereafter. Control (C) group rats were given distilled water orally for 12 days and saline i.p. as single dose on the eleventh day. Animals were scarified one day following the i.p. injection in all groups.

\section{Experimental protocol and assays}

Blood samples were withdrawn from the retroorbital veins into heparinized tubes, centrifuged at $3000 \mathrm{rpm}$ for 10 minutes and plasma were separated and kept at $-20^{\circ} \mathrm{C}$ until analysis. Plasma urea level was detected using Urea- Kit S using urease- modified Berthelot reaction (end point enzymatic determination) at $578 \mathrm{~nm}$ after ${ }^{11}$, plasma creatinine level using Jaffe Colorimetrickinetic at $492 \mathrm{~nm}$ after ${ }^{12}$, IL-6, IL-10, and TNF- $\alpha$ detected using enzyme-linked immunosorbent assay (ELISA) kits following the manufacturer's instructions. The samples were tested in duplicate.

\section{Histology}

Kidney specimens from all groups were taken for histological evaluation. Kidneys were fixed in $10 \%$ neutral buffered formalin for $24 \mathrm{~h}$. After dehydration through a graded alcohol series, the tissues were embedded in paraffin, sectioned at 5 micron thickness stained with hematoxylin and eosin. Semithin sections stained with toluidine blue, before being evaluated using a Leitz light research microscope (Leitz Wetzlar, Germany). Blind analysis of morphological changes was performed. We looked at the integrity of glomeruli (focal glomerular fragmentation, space in corpuscle, swelling and glomerular capillaries; tubular epithelium for dilatation, luminal digestion, loss of the brush border, and nucleus changes; possible apoptotic changes as cell shrinkage or chromatin condensation.

\section{Statistical analysis}

GraphPad Prism 5 (GraphPad Software Inc., La Jolla, CA, USA) was used for data analysis. Data were presented as mean +/-SD. Data were compared among groups using one-way analysis of variance (ANOVA) followed by Bonferroni post hoc test. A $(P)$ value of less than 0.05 was considered to represent a statistically significant difference. 


\section{RESULTS}

\section{Effect of folic acid (FA) versus $F A$ and curcumin} (CUR) on blood urea and creatinine levels:

Treatment with FA as a single dose $250 \mathrm{mg}$ i.p. significantly elevated blood urea level about 3 fold $\left({ }^{* * *} \mathrm{P}<0.005\right)$ and creatinine level $\left({ }^{*} \mathrm{P}<0.05\right)$. Treatment with CUR 200mg/kg orally daily for 11 days prior to FA administration and 1 day thereafter significantly decreased blood urea level compared to folic acid group $\left({ }^{+++} \mathrm{P}<0.005\right)$. There was insignificant difference in blood urea level between control group (C) and CUR+FA group (Fig.1). Treatment with CUR insignificantly decreased blood creatinine level compared to FA group ( $>>$ 0.05). There was insignificant difference in blood creatinine level between control group (C) and CUR+FA group (Fig. 2).

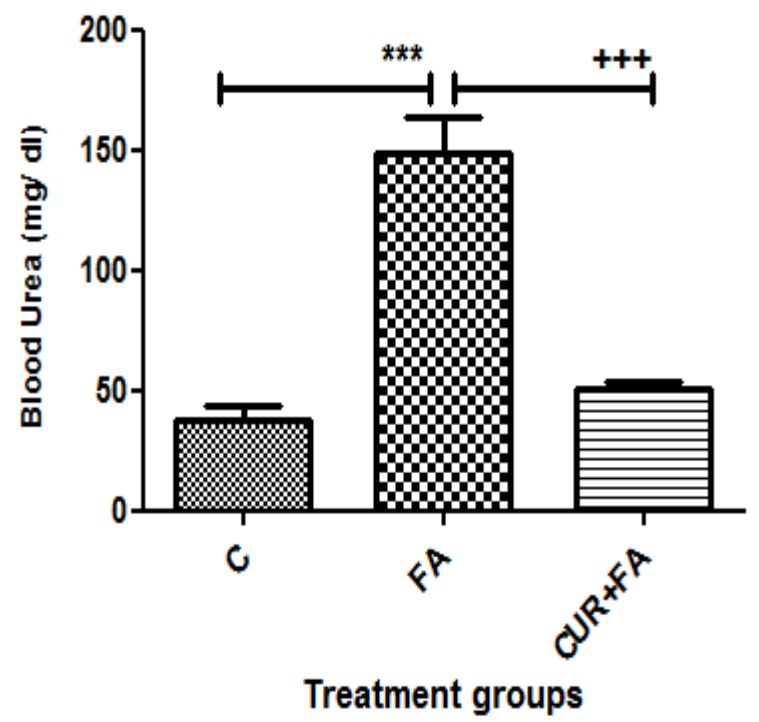

Figure (1): Effect of folic acid (FA) versus FA and curcumin (CUR) to control (C) on blood urea level: C: control; FA: folic acid group; CUR+FA: curcumin and folic acid group. One Way ANOVA with Bonferroni's Multiple Comparison Test. (FA vs FA+CUR to C; ${ }^{* * *} \mathrm{P}<0.005$ FA compared to $\mathrm{C} ;{ }^{+++} \mathrm{P}<0.005$ FA compared to CUR+FA; $n=6)(\mathrm{P} \leq 0.05)$.

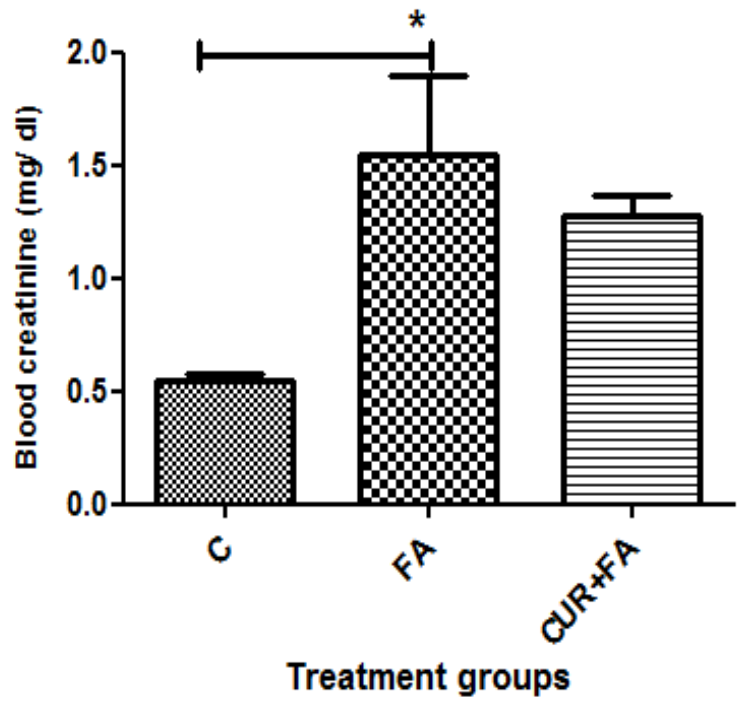

Figure (2): Effect of folic acid (FA) versus FA and curcumin (CUR) to conrol (C) on blood creatinine level: C: control; FA: folic acid group; CUR+FA: curcumin and folic acid group. One Way ANOVA with Bonferroni's Multiple Comparison Test. (FA vs $\mathrm{FA}+\mathrm{CUR}$ to $\mathrm{C} ;{ }^{*} \mathrm{P}<0.05 \mathrm{FA}$ group compared to $\mathrm{C}$ group; $\mathrm{n}=6)(\mathrm{P} \leq 0.05)$.

\section{Effect of folic acid (FA) versus FA and curcumin} (CUR) on blood Cytokines; inter-leukin-6 (IL-6), interleukin-10 (IL-10), and Tumor necrosis factor-alpha (TNF- $\alpha)$ :

Treatment with FA as a single dose $250 \mathrm{mg}$ i.p. significantly elevated blood IL-6 level $\left({ }^{* * *} \mathrm{P}<\right.$ 0.005), IL-10 level ( $\left.{ }^{* * *} \mathrm{P}<0.005\right)$ and TNF- $\alpha$ level $\left({ }^{* * * *} \mathrm{P}<0.005\right)$. Treatment with CUR $200 \mathrm{mg} / \mathrm{kg}$ orally daily for 11 days prior and 1 day after FA injection significantly decreased blood IL-6 level compared to FA group $\left({ }^{+++} \mathrm{P}<0.005\right.$; Fig. 3), IL-10 level compared to FA group $\left({ }^{+++} \mathrm{P}<0.005\right.$; Fig. 4), and TNF- $\alpha$ level compared to FA group $\left({ }^{++} \mathrm{P}<\right.$ 0.01 ; Fig. 5). There was insignificant difference in blood IL-6 or IL-10 levels between C group and CUR+FA group (Fig. 3 \& 4). There was significant difference in blood TNF- $\alpha$ level 
between $\mathrm{C}$ group and CUR+FA group $\left({ }^{\#} \mathrm{P}<0.05\right.$;

Fig. 5).

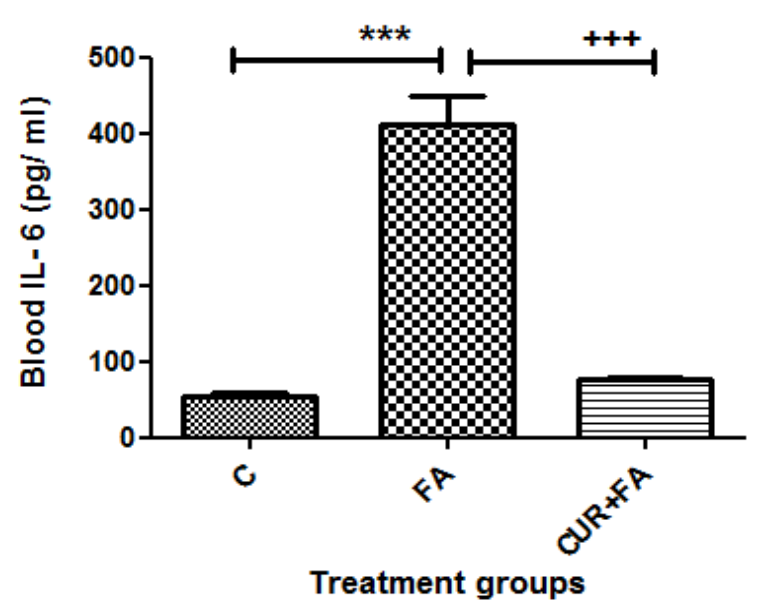

Figure (3): Effect of folic acid (FA) versus FA and curcumin (CUR) to conrol (C) on blood interleukin-6 (IL-6): C: control; FA: folic acid treated group; CUR+FA: curcumin and folic acid group. One Way ANOVA with Bonferroni's Multiple Comparison Test. (FA vs FA+CUR to $\mathrm{C} ;{ }^{* * * *} \mathrm{P}<0.005 \mathrm{C}$ compared to FA; ${ }^{++} \mathrm{P}<0.01$ FA compared to $\left.\mathrm{CUR}+\mathrm{FA} ; \mathrm{n}=6\right)(\mathrm{P} \leq 0.05)$.

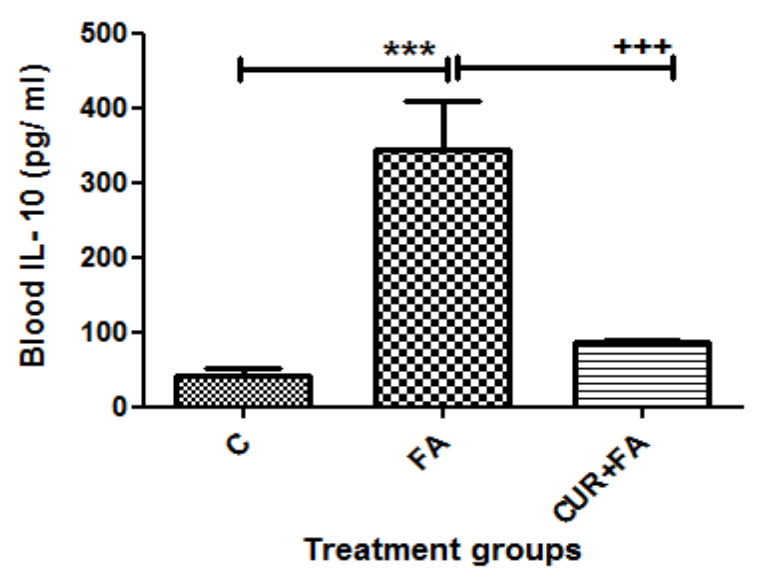

Figure (4): Effect of folic acid (FA) versus FA and curcumin (CUR) to conrol (C) on blood interleukin-10 (IL-10): C: control; FA: folic acid treated group; CUR+FA: curcumin and folic acid group). One Way ANOVA with Bonferroni's Multiple Comparison Test. (FA vs FA+CUR to $\mathrm{C} ;{ }^{* * *} \mathrm{P}<0.005 \mathrm{C}$ compared to FA; ${ }^{+++} \mathrm{P}<0.005$ FA compared to CUR+FA; $\left.\mathrm{n}=6\right) . \quad(\mathrm{P} \leq$ $0.05)$.

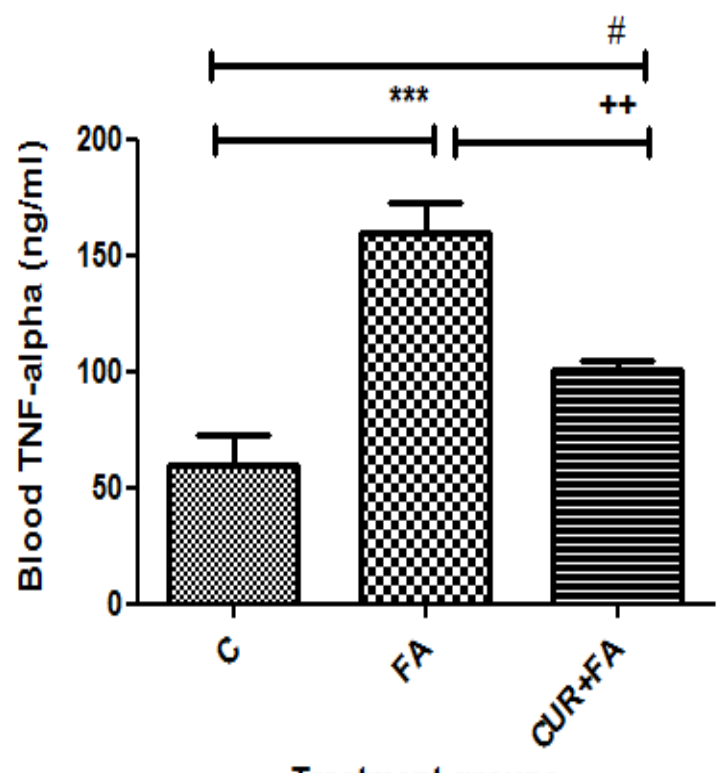

Figure (5): Effect of folic acid (FA) versus FA and curcumin (CUR) to conrol (C) on blood Tumor necrosis factor-alpha (TNF- $\alpha)$ : C: control; FA: folic acid treated group; CUR+FA: curcumin and folic acid group. One Way ANOVA with Bonferroni's Multiple Comparison Test. (FA vs FA+CUR to $\mathrm{C} ;{ }^{* * *} \mathrm{P}<0.005 \mathrm{C}$ compared to $\mathrm{FA} ;{ }^{++} \mathrm{P}<0.01 \mathrm{FA}$ compared to $\mathrm{CUR}+\mathrm{FA} ;{ }^{\#} \mathrm{P}<0.05 \mathrm{C}$ compared to CUR+FA; $n=6)(\mathrm{P} \leq 0.05)$.

\section{Effect of folic acid (FA) versus FA and curcumin (CUR) on renal structure}

Curcumine (CUR) treatment 11 days prior FA administration and 1 day thereafter protected renal tubular cells from damage. Histological examination showed disrupted brush borders flattening of epithelia, condensed nucleus, and plasma membrane blebbings in the kidneys of rats receiving FA (FA) but not of control rats (C), indicating the occurrence of acute tubular necrosis (Fig. 6). CUR ameliorated proximal and distal tubular epithelial cell flattening in the kidney (Fig. 6, FA+CUR). 


\section{Renal structure}

Light microscopy: In the control group animals of the present study the renal cortex was formed of renal corpuscles and proximal and distal convoluted tubules (Figs. 6a and $6 \mathrm{~b}$ ). The renal corpuscle was formed of a tuft of capillaries surrounded by Bowman's capsule consisting of two layers with Bowman's urinary space in between (Fig. 6a). The outer parietal layer was formed of a simple squamous epithelium, whereas the inner visceral layer had modified epithelial cells called podocytes. The proximal convoluted tubules were lined by a cuboidal epithelium with basally located and spherical nuclei and prominent brush border at the apical surface (Figs. 6a and $6 \mathrm{~b})$. The distal convoluted tubules were lined by cuboidal epithelial cells that lacked a brush border. The nuclei were spherical and apically located with pale cytoplasm compared with proximal convoluted tubules (Figs. 6a and 6b).

In the FA treated group rat renal cortex showed marked changes in the renal corpuscles and proximal and distal convoluted tubules. The renal corpuscles showed atrophic shrinkage and retraction of the glomerular tuft of capillaries with dilated Bowman's urinary space (Fig. 6c). There was dilatation of both of the proximal and distal convoluted tubules with flattening of their epithelia, and destruction of the brush border of the proximal convoluted tubules (Figs. 6c and 6d). Cellular necrosis was seen in the form of condensed shrunken nuclei (pyknotic) and nuclear lysis with loss of affinity of its chromatin for basic dyes (karyolytic nuclei), and desquamated cells observed inside the lumen of the tubules (Fig. 6c).
Marked congestion of capillaries was shown as dilated vascular spaces with blood cells (Fig. 6d).

In the renoprotection group (FA + CUR) there was milder cellular destruction as compared to FA treated group, retraction of the glomerular tuft of capillaries with dilation of Bowman's urinary space. The brush border of proximal convoluted tubules is preserved with apparent thickening of its basement membrane however, some dilatation of both of proximal convoluted tubules and distal convoluted tubules were observed (Fig. 6e \& 6f).

\section{DISCUSSION}

This study demonstrated that FA treatment significantly raised blood urea and creatinine levels. This result is supported by several previous studies that proved the role of FA as a model drug for induction of kidney injury manifested by elevation of waste products mainly urea and creatinine $^{2}$. Gupta and his group used two doses of FA $100 \mathrm{mg} / \mathrm{kg}$ for seven days and $250 \mathrm{mg} / \mathrm{kg}$ as single i.p. injection and both doses caused serological changes as well as histopathological renal damage. The efficiency of giving a single dose of FA at $250 \mathrm{mg} / \mathrm{kg}$ i.p. injection for induction of acute renal damage is supported by many previous studies ${ }^{1,2,13}$.

Histological examination of kidney tissues showed that a high single dose of folic acid injection had wide range of toxic effects on the kidney. Widening of the Bowman's urinary space and dilatation of the proximal and distal convoluted tubules were observed indicating the occurrence of acute tubular necrosis. The widening of the Bowman's urinary space may be secondary to 

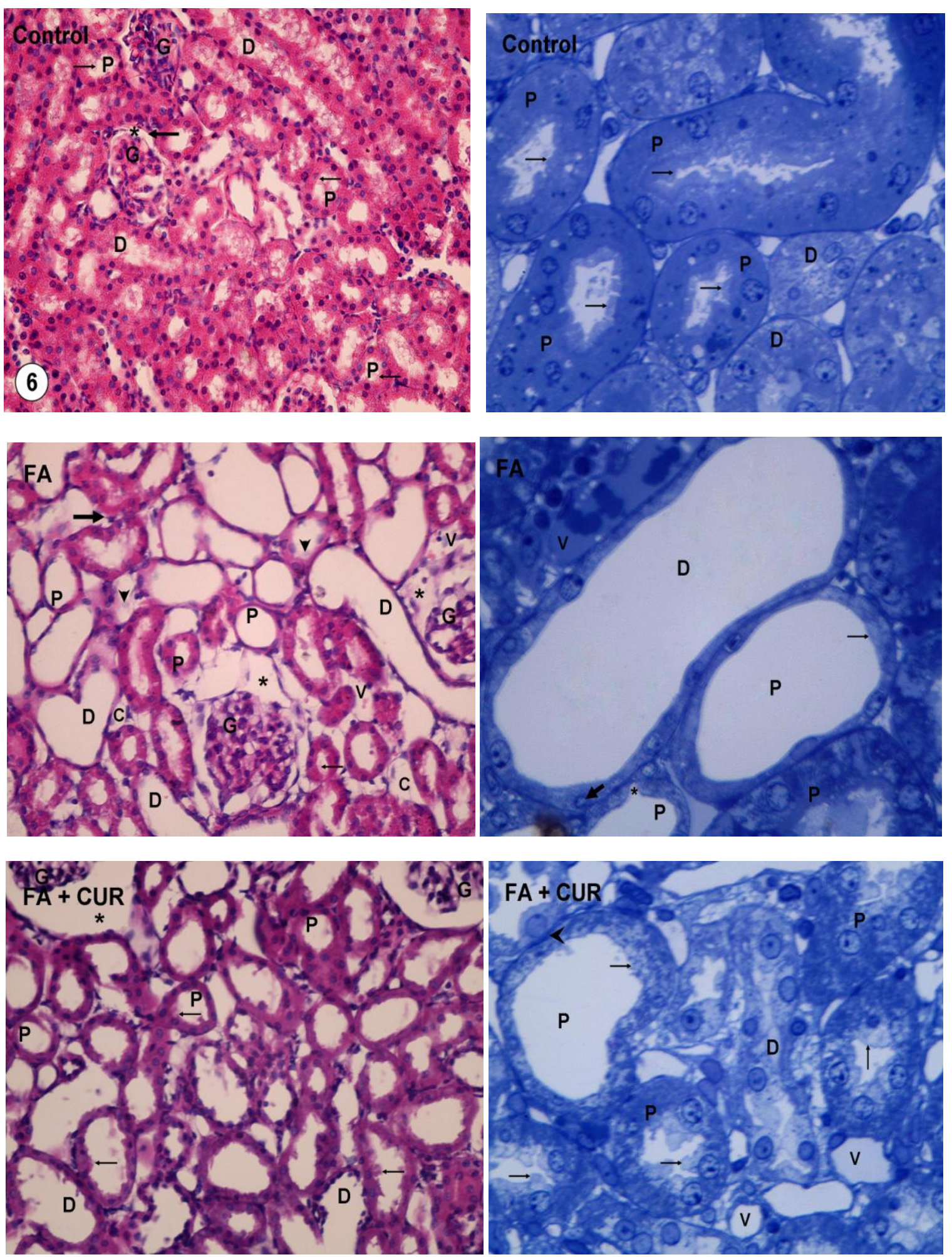

Fig. (6): A photomicrograph of a section of the rat renal cortex from the control group showing a) normal morphology: a glomerular tuft of capillaries (G), Bowman's urinary space (asterisk), the parietal layer of Bowman's capsule (thick arrow), proximal convoluted tubules (P) have a narrower lumen and intact brush border (thin arrow), and distal convoluted tubules (D) have a wider lumen (H \& E, $\times 400)$ and b) parts of proximal convoluted tubules (P) with prominent brush border (thin arrow), and parts of distal convoluted tubules (D) with pale cytoplasm (Toluidine blue, $\times 1000$ ), FA group showing c) atrophic retracted glomerular tuft of capillaries (G) with dilated Bowman's urinary space (asterisk). There is marked cellular destruction, damage of the brush border and dilatation of both of proximal convoluted tubules (P) and distal convoluted tubules (D), and cellular necrosis in the form of pyknotic (thick arrow) and karyolytic (arrowheads) nuclei are seen in some cells. Dilated vascular spaces (V) and cavitations (C) can also be seen (H \& E, × 400), d) showing marked cellular destruction, disruption of the brush border (thin arrow) and dilatation of both of proximal convoluted tubules (P), and distal convoluted tubules (D) with flattening of their epithelia, and cellular necrosis in the form of pyknotic (thick arrow) nuclei are seen in some cells. One of the proximal convoluted tubules shows membrane blebbing of its epithelial lining (asterisk). Marked congestion in capillaries is seen as dilated vascular spaces (V) with blood cells (Toluidine blue, $\times$ 1000), FA + CUR treated group showing e) some retraction of the glomerular tuft of capillaries (G) with dilated Bowman's urinary space (asterisk). There is milder cellular destruction as compared to FA treated group. The brush border (thin arrow) of proximal convoluted tubules (P) is preserved, but some dilatation of both of proximal convoluted tubules (P), and distal convoluted tubules (D) is seen (H \& E, $\times 400)$, and f) milder cellular destruction as compared to FA treated group. The brush border (thin arrow) of proximal convoluted tubules (P) is preserved, but one of the proximal convoluted tubules is dilated with apparent thickening of its basement membrane (arrowhead). Distal convoluted tubule (D) is seen with pale cytoplasm. Dilated vascular spaces (V) can also be seen (Toluidine blue, $\times 1000$ ). 
glomerular atrophy, whereas widening of the proximal tubules may be secondary to destruction of the brush border or due to decreasing height of the lining cells as a result of degeneration.

Previous studies have shown that tubular epithelial cells of FA-induced AKI undergoes apoptosis that is characterized with disruption of brush borders and flattening of epithelia, condensed nuclei, plasma membrane blebbings, DNA fragmentation, and formation of apoptotic bodies ${ }^{14}$. Due to its poor solubility, folic acid at acid $\mathrm{pH}$ precipitates intratubularly as a consequence of fluid reabsorption and increasing acidity along the nephron ${ }^{2,15}$. This intratubular obstruction due to folic acid crystals could be the primary cause of ARF induced by acute administration of folic acid. Apoptosis was observed in the renal tubules epithelium that appeared with highly acidophilic cytoplasm with deeply stained pyknotic nuclei of dying cells. Apoptosis, in general, was triggered by exogenous and endogenous stimuli such as ultraviolet radiation, oxidative stress, and genotoxic chemicals ${ }^{16}$.

The results of this study proved that CUR 200 $\mathrm{mg} / \mathrm{kg}$, given orally for 11 days prior to FA treatment, and one day thereafter, significantly reduced blood urea level and ameliorated the structural damage in rat kidney. Few proximal and distal convoluted tubules were widened, and mild thickening in the basement membrane was observed in CUR+FA group compared to FA group. The apparent thickening of the basement membrane may be secondary to increased collagen fiber formation. Moreover, thickening of the basement membrane might be a part of a healing process to impede the tubular distension. We found insignificant difference in blood creatinine level between FA- and CUR+FA-treated groups. Previous studies showed a reno-protective effect of CUR through lowering blood urea and creatinine level in diabetic nephropathy ${ }^{17}$, in cisplatininduced nephrotoxicity ${ }^{18}$, and in renal ischemia reperfusion injury ${ }^{19}$. In contrast to previous studies, our study showed that CUR lowered the FA-induced elevation of blood urea but failed to lower the creatinine level. This result could be explained on the basis of the difference in the experimental design and the model of AKI.

We found that FA treatment $250 \mathrm{mg} / \mathrm{kg}$ as single dose significantly elevated a known apoptosisinduced inflammatory cytokine TNF- $\alpha$. Our finding is supported by the study of Wan and his colleagues who reported that FA-mediated acute renal failure at $250 \mathrm{mg} / \mathrm{kg}$ is mainly caused by TNF-alpha and the administration of anti-TNFalpha antagonist may be effective for prevention and treatment of acute renal failure ${ }^{13}$. Another in vitro study demonstrated that a member of the TNF superfamily named (TNFSF12) or tumor necrosis factor (TNF)-like weak inducer of apoptosis (TWEAK) act as weak inducer of apoptosis and inflammation processes that play a significant role in renal tubular cell injury ${ }^{20}$. In addition, the work of Nakayama proved that TWEAK-induced cell death in human rhabdomyosarcoma cell line (Kym-1 cells) was indirectly mediated by TNF-alpha and was inhibited by cycloheximide ${ }^{21}$. In our study, folic acid caused marked elevation in the level of tumor necrosis 
factor alpha which inhibits cell growth and proliferation thus leading to apoptosis.

This study also revealed that IL-6 and IL-10 are elevated significantly in FA treated group compared to $\mathrm{C}$ group. This result is supported by previous studies done in several body tissues activated by other pathological factors. One study showed that IL-6 stimulates the inflammatory and autoimmune processes in many diseases such as diabetes and atherosclerosis ${ }^{22,23}$. Previous studies suggest that IL-10 has stimulatory effect on the immune response that helps to scavenge foreign particles whether infectious or noninfectious to reduce inflammation ${ }^{24}$. Other studies revealed that IL-6 has an anti-inflammatory effect that is mediated by inhibition of TNF-alpha and IL-1, and activation of interleukin-1 receptor antagonist (IL$1 R A)$ and IL-10 ${ }^{25}$. Furthermore, IL-6 receptor (IL6R) cleavage is activated by IL-1, TNF- $\alpha$ and apoptosis 26. Moreover, soluble IL-6/IL-6R signaling can be further enhanced, e.g., by IL-10 ${ }^{27}$. Activated skin macrophages and Langerhans cells release IL-1, IL-6, and TNF- $\alpha$ causing proliferation and activation of keratinocytes resulting in early desquamation and late hyperkeratosis as well as fibrosis ${ }^{28}$. Although it is not easy to link increased cytokine levels to pathogenesis, our results suggest that the elevation of not only TNF- $\alpha$, but also IL- 6 and IL-10 may play a major role in FA-induced acute kidney injury.

Moreover, we demonstrated that CUR treatment significantly decreased IL-6, IL-10 and TNF- $\alpha$. These results are supported by a previous study reporting that CUR reduced the levels of IL- 6 and
TNF- $\alpha$ induced by intestinal ischemia-reperfusion on hepatic tissue ${ }^{29}$. Another study proved that curcumin treatment in a dose of $(50 \mathrm{mg} / \mathrm{kg}$ i.p. $)$ beginning 5 days prior to viral infection and daily thereafter for 14 days caused significant reduction of IL-6 and IL-10 in whole lung tissue in a mouse model of acute respiratory distress syndrome ${ }^{30}$. They also reported that CUR treatment caused significant reduction of $\mathrm{NF} \kappa \mathrm{B}$ and the key markers of myofibroblast activation; $\alpha$-smooth muscle actin and Tenascin-C in a mouse model of viral-induced acute respiratory distress syndrome ${ }^{30}$. These findings suggest that CUR is a promising partially protective agent against AKI induced by FA.

\section{Conclusion:}

This study revealed that FA treatment significantly raised blood urea, creatinine, IL-6, IL-10, and TNF- $\alpha$ level and caused marked histological changes in renal epithelial cells. CUR treatment for 12 days significantly reduced blood urea, IL-6, IL-10 and TNF- $\alpha$, and produced marked improvement of kidney structure. This study offers increased understanding of role of folic acid in the induction of AKI and indicates that CUR presents a promising prophylactic treatment for a yet intractable disease.

\section{Conflict of Interest}

There is no conflict of interest.

\section{REFERENCES}

\section{Wen X, Peng Z, Li Y, Wang H, Bishop JV,} Chedwick LR, Singbartl K, Kellum JA: One dose of cyclosporine $\mathrm{A}$ is protective at initiation of folic acid-induced acute kidney injury in mice. Nephrol Dial Transplant. 27 (8):3100-9, 2012. 
2. Gupta A, Puri V, Sharma R, Puri S: Folic acid induces acute renal failure (ARF) by enhancing renal prooxidant state. Exp Toxicol Pathol. 64 (3):225-32, 2012.

3. Hammad FT, Al-Salam S, Lubbad L: Curcumin provides incomplete protection of the kidney in ischemia reperfusion injury. Physiol Res. 14; 61(5):503-11, 2012.

4. Thadhani R, Pascual M, Bonventre JV: Acute Renal Failure. New England Journal of Medicine. 334:1448-1460, 1996.

5. Moreno JA, Izquierdo MC, Sanchez-Niño MD, Suárez-Alvarez B, Lopez-Larrea C, Jakubowski A, Blanco J, Ramirez R, Selgas R, Ruiz-Ortega M, Egido J, Ortiz A, Sanz AB: The inflammatory cytokines TWEAK and $\mathrm{TNF} \alpha$ reduce renal klotho expression through NFkB. J Am Soc Nephrol. 22 (7):1315-25, 2011.

6. Peng ZY, Zhou F, Wang HZ, Wen XY, Nolin TD, Bishop JV, Kellum JA: The anti-oxidant effects are not the main mechanism for glutamine's protective effects on acute kidney injury in mice. Eur J Pharmacol. 5; 705 (13):11-9, 2013.

7. Liu KD, Brakeman PR: Renal repair and recovery. Crit Care Med. 36: S187-S192, 2008.

8. Shi Y, Evans JE, Rock KL: Molecular identification of a danger signal that alerts the immune system to dying cells. Nature 425: 516-521, 2003.

9. Furuichi $\mathrm{K}$, Kaneko $\mathrm{S}$, Wada $\mathrm{T}$ : Chemokine/chemokine receptor mediated inflammation regulates pathologic changes from acute kidney injury to chronic kidney disease. Clin Exp Nephrol. 13: 9-14, 2009.
10. Sanz AB, Justo P, Sanchez-Niño MD, Blanco-Colio LM, Winkles JA, Kreztler M, Jakubowski A, Blanco J, Egido J, RuizOrtega M, Ortiz A: The cytokine TWEAK modulates renal tubulointerstitial inflammation. J Am Soc Nephrol. 19 (4):695-703, 2008.

11. Chaney AL and Marbach EP: (1962) Clin. Chem. 8, 130, 2013.

12. Delanghe $J$ R. and Speeckaert MM: "Creatinine determination according to Jaffewhat does it stand for?". Nephrology Dialysis Transplantation Plus. 4: 83-86, 2011.

13. Wan B, Hao L, Qiu Y, Sun Z, Cao Q, Zhang Y, Zhu T, Wang H, Zhang Y: Blocking tumor necrosis factor-alpha inhibits folic acid-induced acute renal failure. Exp Mol Pathol. 81(3): 2116, 2006.

14. Ortiz, A., Lorz, C., Catalan, M.P: Expression of apoptosis regulatory proteins in tubular epithelium stressed in culture or following acute renal failure. Kidney Int. 57, 969-981, 2000.

15. Huguenin ME, Birbaumer A, Brunner FP, Thorhorst J, Schmidt U, Dubach UC, Thiel G: An evaluation of the role of tubular obstruction in folic acid induced acute renal failure in the rat. Nephron 22:41-54, 1978.

16. Rastogi P, Richa R, Sinha RP: Apoptosis: molecular mechanisms and pathogenicity. EXCLI J. 8: 155-181, 2009.

17. Wu W, Geng H, Liu Z, Li H, Zhu Z: Effect of curcumin on rats/mice with diabetic nephropathy: a systematic review and metaanalysis of randomized controlled trials. J Tradit Chin Med. 34 (4):419-29, 2014.

18. Sahin K, Orhan C, Tuzcu M, Muqbil I, Sahin N, Gencoglu H, Guler O, Padhye SB, 
Sarkar FH, Mohammad RM: Comparative in vivo evaluations of curcumin and its analog difluorinated curcumin against cisplatininduced nephrotoxicity. Biol Trace Elem Res. Feb; 157 (2):156-63, 2014.

19. Chen TH, Yang YC, Wang JC, Wang JJ: Curcumin treatment protects against renal ischemia and reperfusion injury-induced cardiac dysfunction and myocardial injury. Transplant Proc. 45 (10):3546-9, 2013.

20. Justo P, Sanz AB, Sanchez-Niño MD, Winkles JA, Lorz C, Egido J, Ortiz A: Cytokine cooperation in renal tubular cell injury: the role of TWEAK. Kidney Int. 70 (10):1750-8, 2006.

21. Nakayama $M$, Ishidoh $K$, Kayagaki $N$, Kojima Y, Yamaguchi N, Nakano H, Kominami E, Okumura $\mathrm{K}$, Yagita $\mathrm{H}$ :

26. Scheller J, Chalaris A, Schmidt-Arras D, Rose-John S: The pro- and anti-inflammatory properties of the cytokine interleukin-6. Biochim Biophys Acta. 1813 (5):878-88, 2011.

27. Traum D, Timothee P, Silver J, Rose-John S, Ernst M, Larosa DF: IL-10-induced gp130 expression in mouse mast cells permits IL-6 trans-signaling. J Leukoe Biol. 91(3):427-35, 2012.

28. Yamamoto $T$, Eckes $B$, Mauch $C$, Hartmann K, Krieg T. Monocyte chemoattractant protein-1 enhances gene expression and synthesis of matrix metalloproteinase-1 in human fibroblasts by an autocrine IL-1 alpha loop. J Immunol. 164 (12):6174-9, 2000.
Multiple pathways of TWEAK-induced cell death. J Immunol. 15; 168(2):734-43, 2002.

22. Kristiansen OP, Mandrup-Poulsen $T$ : Interleukin- 6 and diabetes: the good, the bad, or the indifferent? Diabetes. 54 Suppl 2:S114-24, 2005.

23. Dubiński A, Zdrojewicz $Z$ : The role of interleukin-6 in development and progression of atherosclerosis. Pol Merkur Lekarski. 22 (130): 291-4, 2007.

24. Asadullah K, Sterry W, Volk HD: Interleukin-10 therapy--review of a new approach. Pharmacol Rev. Jun; 55(2): 241-69, 2003.

25. Schaue D, Kachikwu EL, McBride WH: Cytokines in Radiobiological Responses: A Review Radiat Res. 178 (6): 505-523, 2012.

29. Fan Z, Jing H, Yao J, Li Y, Hu X, Shao H, Shen G, Pan J, Luo F, Tian X: The protective effects of curcumin on experimental acute liver lesion induced by intestinal ischemiareperfusion through inhibiting the pathway of NF- $\mathrm{BB}$ in a rat model. Oxid Med Cell Longev. Vol 2014, ID 191624, 8 pages, 2014.

30. Avasarala S, Zhang F, Liu G, Wang R, London SD, et al: Curcumin Modulates the Inflammatory Response and Inhibits Subsequent Fibrosis in a Mouse Model of Viral-induced Acute Respiratory Distress Syndrome. PLoS ONE 8 (2): e57285. 


\section{الملخص العربى}

\section{دراسة فسيولوجية و تركيبية عن تأثير الكركمين الوقائى ضد إصابات الكلى الحادة الناجمة عن حامض الفوليك في الجرذان البيضاء}

الههف مع أن استخدام حامض الفوليك لاحداث فثل كلوى حاد كثير ا ما استخدم فى التجارب المعلية فإن الآلية التي يحدث بها

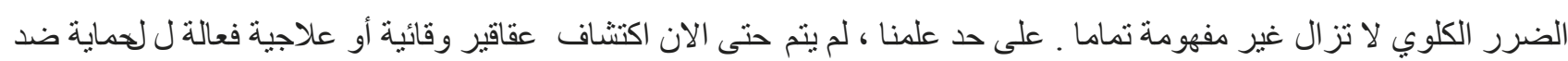

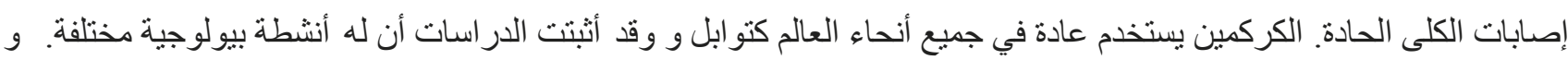

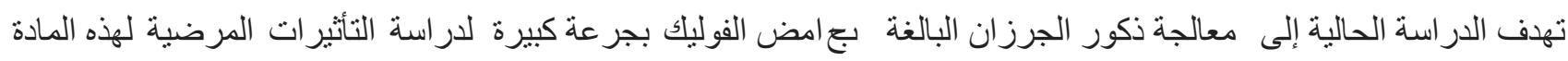
المرتبطة لبلضرر الكلوي الحاد، وايضاح تأثير حامض الفوليك على وظيفة الكلى، و السيتوكينات الالتهابية، و و التغيرات التركيبية

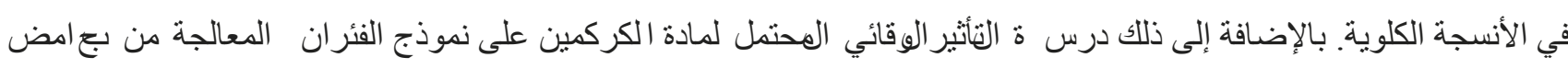
الفوليك لإحدث اصابة الكلى الحادة. الطريقة. تم تقسيم الفئر ان إلى 3 مجمو عات : (1) مجمو عة الجرزان المعالجة بهر عة و احدة من حامض الفوليك ( 250 ملغ / كغ

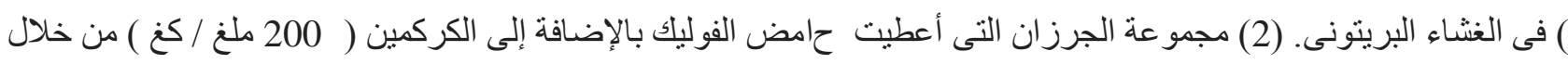
أنبوب تغذية عن طريق الفم يوميا لمدة 11 يوما قبل أن حقن حامض الفوليك اعطئ ( 250 ملغم / كغم ) و الجرعة الأخيرة من الكركمين

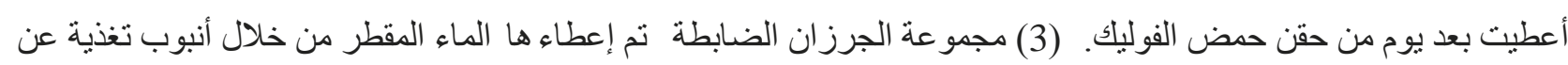

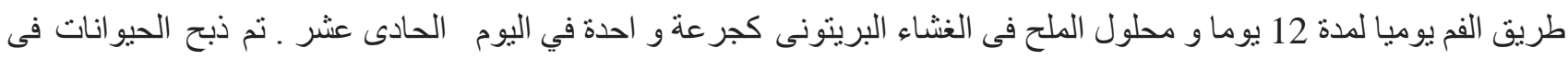
اليوم التالع للهقن في كل المجمو عات ـ تم الكثف عن تدهور وظائف الكلى من خلال قياس مستويات اليوريا في الدم و الكرياتينين .

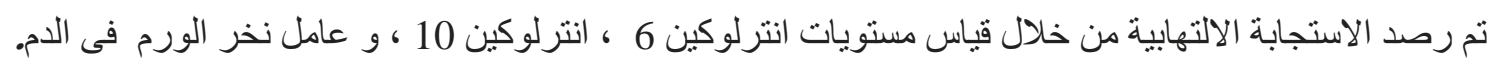
النتائج : وجدنا أن العلاج بـ امض الفوليك أدى الى زيادة نسب اليورياو الكرياتينين في الدم ، و زيادة مستويات انترلوكين 6 ، 6 ،

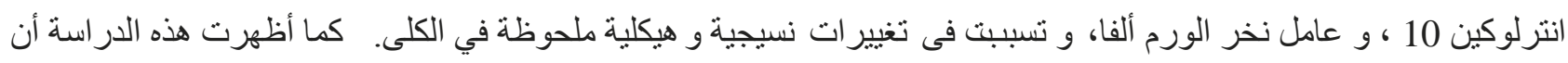

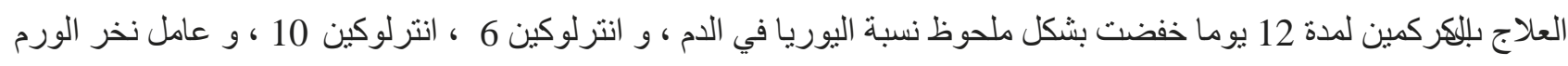
ألفا، كما أدت الى حماية جزئية ضد الأضر ار التى أحدثها حامض الفوليك بالنسيج الكلوي . الاستنتاج. وتثبير هذه النتائج إلى أن الكركمين هو عامل وقائي ضد اصابة الكلى الحادة الناجم ة عن استخدام حامض الفوليك بجر عة عالية. 